\title{
FEATURES OF THE DIAGNOSIS OF MENIERE'S DISEASE ON THE EXAMPLE OF A CLINICAL CASE
}

\author{
Kharina Kateryna, Shepel Veronika, Sazonova Taisiia
}

Introduction. Meniere's disease is accompanied by a non-infectious pathology of the inner ear, during which can lead to systemic labyrinth dizziness, nausea, vomiting, hearing loss and tinnitus in one ear. It is a rare disease, affecting up to 200 cases per 100,000 people.

Aim. The purpose of this article was to analyze the clinical case of a patient with Meniere's disease.

Materials and methods. Patient S., was admitted to the Department of Vascular Pathology of the Brain and Rehabilitation of the State Institution «Institute of Neurology, Psychiatry and Narcology of the NAMS of Ukraine» with complaints of regular attacks of systemic vertigo with a frequency of up to 7 times a week lasting 1-4 hours, sometimes accompanied by vomiting, constant noise and whistling in the left ear. He considers himself ill since 05.11.19, when during training in the gym there was the first case of dizziness and vomiting, which lasted 3 hours. In August 2019, the attacks continued, became more frequent and prolonged, passed on their own, sometimes in a specific position of the head - the head tilted forward with the neck stretched out. Neurological examination revealed that the palpebral fissures and pupils were equal. Eye movements are full, painless. Convergence insufficiency was examined. Corneal reactions are reduced. Horizontal positioning nystagmus was examined. There are no pathological signs, no sensory disturbances. The patient performed coordination tests with uncertainty. The patient showed unsteadiness during Romberg's test. The patient felt pain during the palpation of paravertebral points. The patient experienced exaggerated changes in mood.

Results. 1. Brain MRI results showed a thinning and a decrease in the MR signal on T2 from the cochlea of the inner ear to the left. CT scanning of the mastoid processes revealed an increased density of bone structures of the labyrinth nucleus on the left. 2. During the otoneurological examination, the asymmetry of vestibular responses along the labyrinth, slight stimulation of the left labyrinth were established. The patient was diagnosed with peripheral cochleovestibular syndrome on the left, Meniere's syndrome.

Conclusions. This clinical case illustrates the importance of collecting a detailed medical history and examination of a patient with complaints of dizziness, hearing loss, tinnitus, and repeated vomiting. To establish a diagnosis and develop a treatment plan for a patient, the coordinated work of a multidisciplinary group is required, which should consist of a neurologist, audiologist, and otolaryngologist.

KEY WORDS: Meniere's disease, dizziness, deafness, imbalance

\section{INFORMATION ABOUT AUTHORS}

Kharina Kateryna V., MD, PhD, Assistant of the Department of Clinical Neurology, Psychiatry and Narcology of V. N. Karazin Kharkiv National University, 6, Svobody sq., Kharkiv, Ukraine, 61022, e-mail: k.kharina@karazin.ua, ORCID ID: http://orcid.org/0000-0002-4802-4656

Shepel Veronika, student of V. N. Karazin Kharkiv National University, School of Medicine, 6, Svobody sq., Kharkiv, Ukraine, 61022, e-mail: nikysa41@ gmail.com, ORCID ID: https://orcid.org/0000-0002-8908-2457

Sazonova Taisiia, student of V. N. Karazin Kharkiv National University, School of Medicine, 6, Svobody sq., Kharkiv, Ukraine, 61022, e-mail: sazonovataya@gmail.com, ORCID ID: https://orcid.org/0000-0001-5084-5085

\section{INTRODUCTION}

Meniere's disease (MD) is a nonsuppurative disease of the inner ear, the clinical symptoms of which are caused by an increase in endolymph volume and an increase in intralabyrinth pressure, and it leads to the development of progressive deafness, tinnitus, systemic dizziness, imbalance and autonomic disorders [1].
According to the literature, MD affects from 10 to 190 people per 100,000 people, most of whom are women. The average age of patients is $20-50$ years $[1,2]$.

MD can begin with both vestibular and auditory (hearing loss, congestion and tinnitus) symptoms. In the early years of the development of the disease, hearing loss may fluctuate with almost complete recovery of hearing in the period between attacks. Later, 
hearing gradually decreases to complete deafness [3].

Dizziness in Meniere's disease is accompanied by spontaneous nystagmus, ataxia, coordination disorders, severe autonomic dysfunction, such as hypersalivation, hyperhidrosis, changes in blood pressure, dyspeptic disorders. A hypothesis has been put forward that the characteristic attacks of dizziness can be caused by a sudden movement of the volume of endolymph from the cochlea to the upper part [4]. The attack can last from several minutes to several days. Ataxia and coordination disorders can persist for several days after an attack. Diagnosis is usually based on anamnesis and clinical symptoms.

Difficulties in diagnosing MD may be due to the fact that many patients whose disease begins with attacks of dizziness cannot clearly describe their complaints. In addition, there are a number of diseases and conditions accompanied by vestibular disorders that require differential diagnosis of MD: benign paroxysmal positional vertigo, vertebrobasilar insufficiency, craniocerebral trauma, vestibular neuritis, labyrinthine fistula, labyrinthitis, consequences of otosurgical procedures, multiple sclerosis, acute otitis media, hyperventilation, side effects of drugs $[5,6]$.

\section{CLINICAL CASE}

Man, 27 years old, a resident of the Kharkiv city.

\section{COMPLAINTS}

Patient S. was admitted to the Department of Vascular Pathology of the Brain and Rehabilitation Department of State Institution «Institute of Neurology, Psychiatry and Narcology of the NAMS of Ukraine» and complained about regular attacks of systemic vertigo with a frequency of up to 7 times a week lasting 1-4 hours, vomiting, tinnitus in the left ear.

Patient S. was admitted to the Department of Vascular Pathology of the Brain and Rehabilitation Department of State Institution «Institute of Neurology, Psychiatry and Narcology of the NAMS of Ukraine» and complained about regular attacks of systemic vertigo with a frequency of up to 7 times a week lasting 1-4 hours, vomiting, tinnitus in the left ear.

He considers himself ill since 05.11.19 when during training in the gym there was the first case of dizziness with an attack of vomiting, which lasted for 3 hours. In August 2019, the seizures continued, became more frequent (every day), became longer (from 40 minutes to 4 hours), passed on their own, sometimes with a specific head position - the head tilted forward with the neck stretched out. After another attack on 15.11.19, which lasted about 4 hours, he went to the State Institution «Institute of Neurology, Psychiatry and Narcology of the NAMS of Ukraine» and was hospitalized in the Department of Vascular Pathology of the Brain and Rehabilitation for a more detailed examination, diagnosis and treatment.

\section{ANAMNESIS VITAE}

The patient denies intestinal infections, hepatitis, malaria, helminthic infestations, diabetes mellitus, tuberculosis. Allergic history was unremarkable. No blood transfusions were performed. According to the patient - mitral valve prolapse of the stage I with minor mitral regurgitation was present. The patient is not observed by cardiologists.

\section{OBJECTIVE STATUS}

Consciousness is clear, the skin is pale pink, peripheral lymph nodes are not enlarged. The facial expression is calm. Body mass index $24,49 \mathrm{~kg} / \mathrm{m}^{2}$. The thyroid gland is undetectable. The isthmus of the thyroid gland is palpable, painless. The musculoskeletal system is developed at a sufficient level. The shape of the chest is normosthenic, there are no chest deformities. During the percussion of the lungs, a clear lung sound was observed on both sides. During the auscultation, vesicular breathing is heard, no wheezing. The boundaries of relative cardiac dullness were not shifted. Heart rate was 80 beats/min., abnormal heart sounds are not heard. Rhythmic pulse, medium filling was identified. Blood pressure was 120/75 mm Hg. The abdomen was of normal size, soft and painless; the lower border of the liver is along the edge of the costal margin. During the neurological examination, the palpebral fissures and pupils were equal. Photoreactions were live. Eye movements are full, painless. Convergence insufficiency was examined. Corneal reactions were reduced. Horizontal shallow setting nystagmus was observed. Asymmetry in the facial innervation is not revealed. The decreased hearing was found. There were no pathological signs, no sensory disturbances. The patient performed 
coordination tests with uncertainty. The patient showed unsteadiness during Romberg's test. The patient felt pain during the palpation of paravertebral points. The patient experienced exaggerated changes in mood.

\section{RESULTS OF THE INVESTIGATIONS}

During the echocardiography examination (ECHO-KG) (18.11.19), echo signs of prolapse of the I degree with minor mitral regurgitation, relative insufficiency of the pulmonary artery valve were found. Left ventricular systolic function was within normal limits.

MRI examination of the brain (16.11.19): Behind the cerebellar worm, a local expansion of the subarachnoid space up to $3.3 \times 1.3 \mathrm{~cm}$ was determined. There was the thinning and decrease in the MR signal on T2 from the cochlea of the inner ear on the left. In the basal parts of the left maxillary sinus, a cystic formation up to $1.3 \times 1.0 \mathrm{~cm}$ was visualized. Conclusion: Retrocerebellar arachnoid cyst is a variant of development. There were indirect signs of sclerotic changes in the cochlea of the labyrinth of the inner ear on the left.

Computed tomography (CT) scan of the mastoid process (20.11.19): ventilation of the mastoid cells was not impaired. Increased density of bone structures of the labyrinth nucleus was detected on the left. There was no data on the violation of the integrity of bone structures.

Otoneurological study (20.11.19): Asymmetry of vestibular reactions along the labyrinth, slight stimulation of the left labyrinth. During the overturn test, the excitability of the labyrinths was symmetrical, slightly increased.

\section{RECOMMENDED DRUG THERAPY}

Treatment was prescribed: medogistin, vestinorm, meksiprim, platifilin, vinpocetine, magnesium sulfate, diclofenac, renalgan, carbamazepine.

During the stay in the hospital, attacks of systemic vertigo were observed twice, accompanied by tinnitus in the left ear lasting about 20-30 minutes, which passed without medication, the patient took a forced position, ensuring peace. Discharged under the supervision of a neurologist at the place of residence and for further examination by an otoneurologist. Betaserc (medogistin) $24 \mathrm{mg} 2$ times a day for 2 months was prescribed on an outpatient basis, vertinex 1 tab. 2 times a day -
1 month, Cavinton 1 tab. 3 times a day -1 month, carbamazepine $2001 / 2$ tab. 2 times a day -4 months.

\section{DISCUSSION}

Meniere's disease is a rare, chronic disease. A thorough differential diagnosis is required for the diagnosis. This clinical case confirms that a correctly collected anamnesis and examination of a patient, as well as correctly selected methods of further instrumental diagnostics, are fundamentally important for establishing a diagnosis and successful treatment in the future.

Despite numerous studies, the etiology and pathogenesis of Meniere disease have not been reliably established. There is a hypothesis that a genetic predisposition plays an important role in the pathogenesis of Meniere's disease, namely the anatomical features of the structure of the inner ear [7]. Also, there are suggestions that the development of Meniere disease is associated with connective tissue pathology. Based on the data of the clinical case, it can be assumed that Meniere's disease occurred in this patient due to violations of the intrauterine anlage of connective tissue [4]. This assumption may be supported by the patient's mitral valve prolapse and pulmonary valve insufficiency.

The American Academy of Otorhinolaryngology and Head and Neck Surgery (AAOHNS) has developed diagnostic criteria for the diagnosis of Meniere's disease. These criteria were revised by the Committee of the Bárány Society, The Japan Society for Equilibrium Research, The European Academy of Otology and Neurotology (EAONO), The Equilibrium Committee of the American Academy of Otolaryngology-Head and Neck Surgery (AAO-HNS) and the Korean Balance Society in 2020 [2].

The criteria for making a diagnosis were identified: two or more spontaneous attacks of dizziness lasting from 20 minutes to 12 hours; sensorineural hearing loss at low and medium frequencies confirmed by audiography during or after an attack of dizziness; fluctuating auditory symptoms: hearing loss, feeling of fullness in the ear; absence of the causes of these symptoms [2].

There are three main variants of the course of the disease. In the first variant (cochlear form), auditory disorders first occur, and then vestibular. In the second (classical) variant, auditory and vestibular disorders appear simultaneously, the first attack of dizziness is 
accompanied by hearing loss and tinnitus. In the third (more rare) variant of the course (the vestibular form of Meniere disease), the disease begins with vestibular dizziness [2].

Differential diagnosis of Meniere disease diagnosis of MD should be performed with a wide range of diseases. Differential diagnosis is most difficult during the early stages of Meniere disease during the first attacks. First of all, it is important to perform differential diagnosis with vestibular neuronitis, and in the case of recurrent vestibular crises - with vestibular migraine [7]. The duration of an attack of dizziness helps to distinguish Meniere disease from vestibular neuronitis: if it is Meniere disease, the attack usually lasts several hours - no more than a day, then if it is vestibular neuronitis, constant systemic dizziness persists for at least several days. Special attention should be paid to the differential diagnosis of Meniere disease with perilymphatic fistula, especially if there is a traumatic factor in the anamnesis. Repeated attacks of dizziness, a history of headache are the diagnostic criterias of vestibular migraine and it makes it possible to differentiate it from Meniere disease.

Vestibular migraine is characterized by the presence of oculomotor disorders in the form of numbness and speech impairment during an attack of dizziness, and in the interictal period the absence of hearing loss, despite frequent attacks in history [8]. In addition to vestibular migraine, Meniere disease should be differentiated from a number of diseases of the central nervous system, accompanied by vestibular disorders. First of all, this is an acute disturbance of blood supply in the anterior inferior cerebellar or labyrinth arteries, multiple sclerosis, less often congenital ear anomalies, arachnoid cysts of the posterior cranial fossa, syphilis, Lyme disease.

\section{CONCLUSIONS}

This clinical case illustrates the importance of collecting a detailed medical history and examination of a patient with complaints of dizziness, hearing loss, tinnitus, and repeated vomiting. Such patients need constant monitoring, as symptoms can progress rapidly and the condition worsens over time. Differential diagnosis with other pathologies that are accompanied by vestibular disorders is important.

To assess the patient's condition, establish a diagnosis and develop a treatment plan, a wellcoordinated work of a multidisciplinary team is required, which should include: a neurologist, audiologist, otolaryngologist. In the treatment of patients with Meniere's disease, symptomatic therapy is used, which, in accordance with the recommendations, is aimed at stopping the main clinical implications and improving the quality of life.

\section{REFERENCES}

1. Gibson WPR. Meniere's Disease. Advances in Oto-Rhino-Laryngology. 2019; 82: 77-86. Available from: doi:10.1159/000490274

2. Basura GJ, Adams ME, Monfared A, et al. Clinical Practice Guideline: Ménière's Disease Executive Summary. Otolaryngology-Head and Neck Surgery. 2020; 162 (4): 415-434. Available from: doi:10.1177/0194599820909439

3. Nakashima T, Pyykkö I, Arroll MA, et al. Meniere's disease. Nature reviews Disease primers. 2016; 2: 16028. Available from: doi:10.1038/nrdp.2016.28

4. Gürkov R, Pyykö I, Zou J, Kentala E. What is Menière's disease? A contemporary re-evaluation of endolymphatic hydrops. Journal of neurology. 2016; 263 Suppl 1: S71-S81. Available from: doi:10.1007/s00415-015-7930-1

5. Tabet P, Saliba I. Meniere's Disease and Vestibular Migraine: Updates and Review of the Literature. Journal of Clinical Medicine Research. 2017; 9 (9): 733-744. Available from: doi:10.14740/jocmr3126w

6. Perez-Carpena P, Lopez-Escamez JA. Current Understanding and Clinical Management of Meniere's Disease: A Systematic Review. Seminars in neurology. 2020;40(1): 138-150. Available from: doi:10.1055/s-0039-3402065

7. Clyde JW, Oberman BS, Isildak H. Current Management Practices in Ménière's Disease. Otology \& Neurotology. 2017; 38 (6): e159-e167. Available from: doi:10.1097/MAO.0000000000001421

8. Shin CH, Kim Y, Yoo MH, et al. Management of Ménière's Disease: How Does the Coexistence of Vestibular Migraine Affect Outcomes? Otology \& Neurotology. 2019; 40 (5): 666-673. Available from: doi:10.1097/MAO.0000000000002176 


\section{ОСОБЛИВОСТІ ДІАГНОСТИКИ ХВОРОБИ МЕНЬЕРА НА ПРИКЛАДІ КЛІНІЧНОГО ВИПАДКУ}

Харіна К. В., Шепель В. В., Сазонова Т. М.

Вступ. Хвороба Меньєра супроводжується патологією внутрішнього вуха неінфекційного характеру, під час якого виникають напади системного лабіринтового запаморочення, що супроводжується нудотою і блювотою, зниженням слуху і шумом в одному вусі. Цей розлад складно діагностувати, оскільки пацієнти, захворювання у яких починається 3 нападів запаморочення, не можуть чітко описати свої скарги.

Мета. Метою даної статті був аналіз клінічного випадку пацієнта з хворобою Меньєра.

Матеріали та методи. Хворий С. поступив у відділення судинної патології головного мозку та реабілітації ДУ «Інститут неврології, психіатрії та наркології НАМН України» зі скаргами на регулярні напади системного запаморочення з частотою до 7 разів на тиждень тривалістю 1-4 години, які іноді супроводжувалися блювотою, постійним шумом і свистом в лівому вусі. Неврологічне обстеження показало, що очні щілини і зіниці в нормі. Рухи очей повні, безболісні. Була виявлена недостатність акта конвергенції. Корнеальні реакції знижені. Був виявлений горизонтальний ністагм. Сенсорних порушень не було виявлено. Пацієнт невпевнено виконував координаційні проби, була виявлена хиткість в позі Ромберга.

Результати. 1. При аналізі результатів МРТ головного мозку, виявлено потоншення і зниження МР-сигналу на Т2 від равлики внутрішнього вуха зліва. При КТ-сканування сосковидних відростків виявлена підвищена щільність кісткових структур ядра лабіринту сторінки. 2. Під час отоневрологіческого дослідження встановлена асиметрія вестибулярних реакцій по лабіринту, легке збудження лівого лабіринту. Поставлено діагноз: периферичний кохлеовестибулярний синдром зліва, синдром Меньєра.

Висновки. Даний клінічний випадок ілюструє важливість детального збору анамнезу та обстеження пацієнта зі скаргами на запаморочення, зниження слуху, наявність шуму у вухах, багаторазове блювання. Для встановлення діагнозу і розробки плану лікування пацієнта необхідна злагоджена робота мультидисциплінарної групи.

КЛЮЧОВІ СЛОВА: хвороба Меньєра, запаморочення, глухота, порушення рівноваги

\section{ІНФОРМАЦІЯ ПРО АВТОРІВ}

Харіна Катерина Василіївна, к.мед.н., асистент кафедри клінічної неврології, психіатрії та наркології, майдан Свободи 6, Харків, Україна, 61022, e-mail: k.kharina@karazin.ua, ORCID ID: http://orcid.org/0000-0002-4802-4656

Шепель Вероніка Віталіївна, студентка Харківського національного університету імені В. Н. Каразіна, медичний факультет, майдан Свободи, 6, Харків, Україна, 61022, e-mail:nikysa41@gmail.com, ORCID ID: https://orcid.org/0000-0002-8908-2457

Сазонова Таїсія Михайлівна, студентка Харківського національного університету імені В. Н. Каразіна, медичний факультет, майдан Свободи, 6, Харків, Україна, 61022, e-mail: sazonovataya@gmail.com, ORCID ID: https://orcid.org/0000-0001-5084-5085

\section{ОСОБЕННОСТИ ДИАГНОСТИКИ БОЛЕЗНИ МЕНЬЕРА НА ПРИМЕРЕ КЛИНИЧЕСКОГО СЛУЧАЯ}

Харина К. В., Шепель В. В., Сазонова Т. М.

Вступление. Болезнь Меньера сопровождается патологией внутреннего уха неинфекционного характера, во время которого возникают приступы системного лабиринтного головокружения, что сопровождается тошнотой и рвотой, снижением слуха и шумом в одном ухе. Это расстройство сложно диагностировать, поскольку пациенты, заболевание у которых начинается с приступов головокружения, не могут четко описать свои жалобы.

Цель. Целью данной статьи был анализ клинического случая пациента с болезнью Меньера.

Материалы и методы. Больной С. поступил в отделение сосудистой патологии головного мозга и реабилитации ГУ «Институт неврологии, психиатрии и наркологии НАМН Украины» с жалобами на регулярные приступы системного головокружения с частотой до 7 раз в неделю продолжительностью 1-4 часа, которые иногда сопровождались рвотой, постоянным шумом и свистом в левом ухе. Неврологическое обследование показало, что глазные щели и зрачки в норме. Движения глаз полные, безболезненные. Была обнаружена недостаточность акта конвергенции. Корнеальные реакции 
снижены. Был обнаружен горизонтальный нистагм. Сенсорных нарушений не было обнаружено. Пациент неуверенно выполнял координационные пробы, была обнаружена шаткость в позе Ромберга.

Результаты. 1. При анализе результатов МРТ головного мозга, обнаружено истончение и снижение МР-сигнала на Т2 от улитки внутреннего уха слева. При КТ-сканировании сосцевидных отростков обнаружена повышенная плотность костных структур ядра лабиринта слева. 2. Во время отоневрологического исследования установлена асимметрия вестибулярных реакций по лабиринту, легкое возбуждение левого лабиринта. Поставлен диагноз: периферический кохлеовестибулярный синдром слева, синдром Меньера.

Выводы. Данный клинический случай иллюстрирует важность детального сбора анамнеза и обследования пациента с жалобами на головокружение, снижение слуха, наличие шума в ушах, многократную рвоту. Для установления диагноза и разработки плана лечения пациента необходима слаженная работа мультидисциплинарной группы.

КЛЮЧЕВЫЕ СЛОВА: болезнь Меньера, головокружение, глухота, нарушение равновесия

\section{ИНФОРМАЦИЯ ОБ АВТОРАХ}

Харина Екатерина Васильевна, к.мед.н., ассистент кафедры клинической неврологии, психиатрии и наркологии, площадь Свободы, 6, Харьков, Украина, 61022, e-mail: k.kharina@karazin.ua, ORCID ID: http://orcid.org/0000-0002-4802-4656

Шепель Вероника Витальевна, студентка Харьковского национального университета имени В. Н. Каразина, медицинский факультет, площадь Свободы, 6, Харьков, Украина, 61022. e-mail: nikysa41@gmail.com, ORCID ID: https://orcid.org/0000-0002-8908-2457

Сазонова Таисия Михайловна, студентка Харьковского национального университета имени В. Н. Каразина, медицинский факультет, площадь Свободы, 6, Харьков, Украина, 61022, e-mail: sazonovataya@gmail.com, ORCID ID: https://orcid.org/0000-0001-5084-5085 